\title{
Male with myelofibrosis and ulceronecrotic lesions
}

\author{
Flávia da Silva Domingos Santos ${ }^{1}$ \\ Priscila Vinhal Grupioni² \\ Loan Towersey ${ }^{3}$ \\ Fred Bernardes Filho ${ }^{\mathbf{1} 4}$
}

1. Department of Internal Medicine, São Francisco Hospital, Ribeirão Preto, SP, Brasil 2. Department of Oncology, São Francisco Hospital, Ribeirão Preto, SP, Brasil 3. AIDS Division, Carlos Tortelly Municipal Hospital, Ministry of Health, Niterói, RJ, Brasil 4. Dermatology Division, Department of Medical Clinics, Ribeirão Preto Medical School, University of São Paulo, Ribeirão Preto, SP, Brasil

\section{SUMMARY}

Granulocytic sarcoma also called myeloid sarcoma is an extramedullary tumour of immature granulocytic cells. It is a rare entity, and mostly accompanied by acute myeloid leukaemia. It is observed during the course of myeloproliferative disorders especially in chronic myeloid leukaemia and myelodysplastic syndromes. Here, we report a case of a 60-year-old male with past history of myelofibrosis admitted to the emergency room due ulceronecrotic lesions, fever and dysphagia. We emphasize the importance of recognizing this entity and its severity.

KEYWORDS: Sarcoma, Myeloid. Leukaemia. Primary myelofibrosis.

\section{CASE}

A 60-year-old man was admitted to the emergency room due ulceronecrotic lesions, fever and dysphagia in the last 15 days. He was in follow-up of hypertension and myelofibrosis for three years without complications. On physical examination, periorbital oedema, ulceronecrotic lesions in ocular, oral and genital mucosae (Figure 1), erythematous and purplish lesions on lower limbs, toes (Figures 2 and 3) and face, cervical, axillary, and inguinal lymph node enlargement, and hepatosplenomegaly were observed. Histopathology of a skin lesion on right thigh showed perivascular inflam-

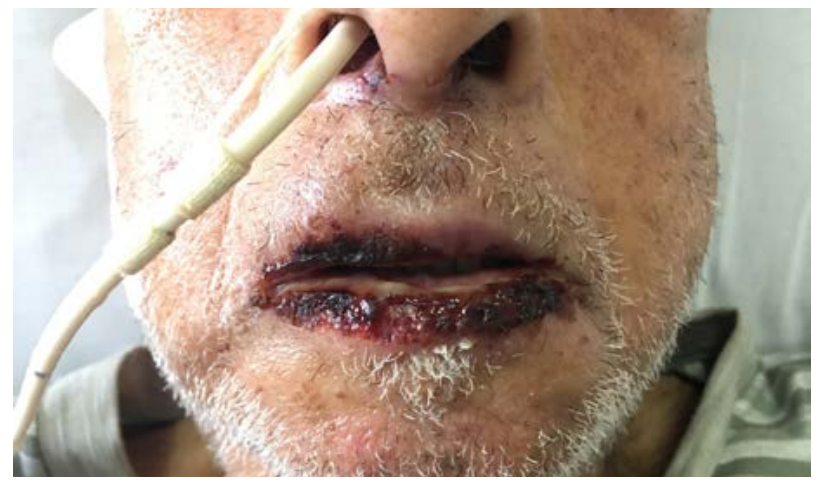

FIGURE 1: MULTIPLE EROSIONS AND CRUSTS ARE PRESENT ON THE LIPS AND NASAL VESTIBULES. 


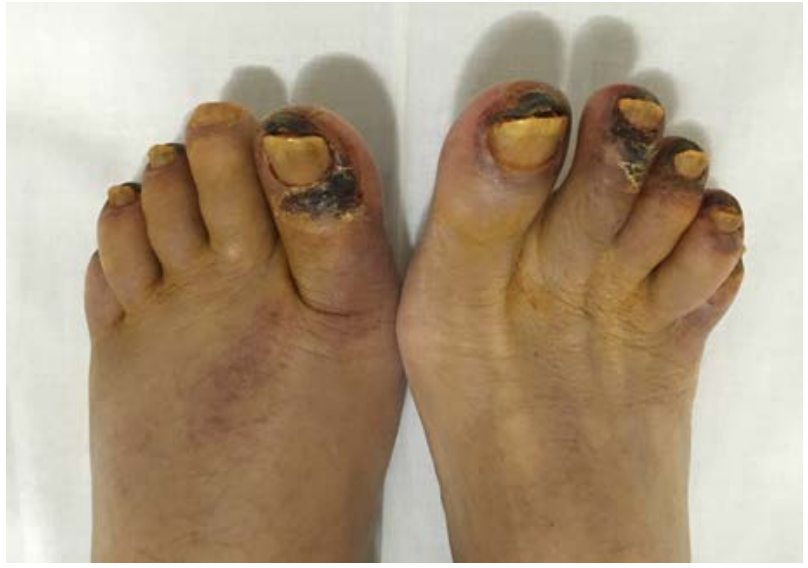

FIGURE 2: ERYTHEMATOUS, CYANOTIC LESIONS AND BLACKENED ERYTHEMATOUS LESIONS ON THE TOES.

matory infiltrate of granulocytic cells in the dermis and subcutaneous with areas of necrosis; no signs of vasculitis. In immunohistochemical evaluation, there was staining for CD3, CD34, CD117, and myeloperoxidase; $\mathrm{CD} 20$ was negative.

\section{DISCUSSION}

Granulocytic sarcoma, chloroma or extramedullary myeloid tumour, is a tumour mass of myeloblasts or immature myeloid cells that appears in extramedullary sites, especially bone tissue. ${ }^{1}$ It is a rare variant of myeloid neoplasia, formerly known as chloroma, because of its greenish colour,

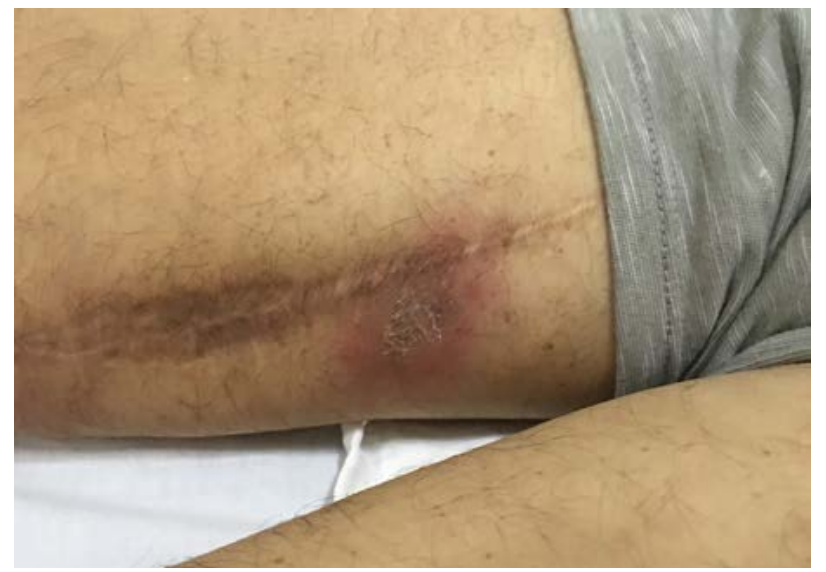

FIGURE 3: INFILTRATED ERYTHEMATOUS PLAQUE ON THE RIGHTTHIGH.

secondary to the expression of myeloperoxidase., ${ }^{1,2}$

Cutaneous lesions in patients with myelodysplastic syndrome can be separated into non-specific (vasculitis, infections, neutrophilic dermatosis, ecchymosis, panniculitis and erythema multiform) and specific lesions defined by the presence of malignant hematopoietic cells in the skin. ${ }^{2,3}$ The occurrence of cutaneous granulocytic sarcoma in the context of myelodysplastic syndromes is rare and often a sign of poor prognosis. ${ }^{2}$ Clinicians must hence be aware to diagnose these lesions early because they can precede peripheral blood and bone marrow transformation to acute myelogenous leukaemia.

\section{RESUMO}

O sarcoma granulocítico, também chamado de sarcoma mieloide, é um tumor extramedular de células granulocíticas imaturas. É uma entidade rara, e principalmente acompanhada de leucemia mieloide aguda. É observado durante o transtorno mieloproliferativo, especialmente na leucemia mieloide crônica e síndromes mielodisplásicas. Aqui, relatamos um caso de um homem de 60 anos com antecedente de mielofibrose admitida na sala de emergência devido a lesões ulceronecróticas, febre e disfagia. Enfatizamos a importância de reconhecer essa entidade e sua gravidade.

PALAVRAS-CHAVE: Sarcoma mieloide. Leucemia. Mielofibrose primária.

\section{REFERENCES}

1. Nizery-Guermeur C, Le Gall-lanotto C, Brenaut E, Couturier MA, Talagas $M$, Andrieu-Key $S$, et al. Cutaneous granulocytic sarcoma and Koebner phenomenon in a context of myelodysplastic syndrome. JAAD Case Rep. 2015;1(4):207-11

2. Orofino N, Cattaneo D, Bucelli C, Pettine L, Fabris S, Gianelli U, et al. An unusual type of myeloid sarcoma localization following myelofibrosis: a case report and literature review. Leuk Res Rep. 2017;8:7-10.

3. Farah C, Bulai Livideanu C, legu J, Paul C, Viraben R, Lamant L, et al. Prevalence and prognostic value of cutaneous manifestations in patients with myelodysplastic syndrome. J Eur Acad Dermatol Venereol. 2010;24(10):1171-5. 